\title{
A QUANTITATIVE IN VITRO RESPONSE TO FOLLICLE-STIMULATING HORMONE
}

\author{
MARGARET RYLE \\ Department of Clinical Endocrinology, Birmingham and Midland Hospital for Women, \\ Birmingham 11
}

(Received 25th May 1968, revised 8th Fuly 1968)

\begin{abstract}
Summary. A series of six factorial experiments is described in which ovaries of 15-day-old mice were cultured in vitro for 2 to 4 days in the presence of various concentrations of highly purified FSH and LH. The uptake of $\left[{ }^{14} \mathrm{C}\right]$ thymidine by the tissue was measured in all experiments. FSH consistently and significantly increased the uptake where the mice used were above a certain size. In only two experiments did LH significantly increase thymidine uptake; this effect appeared to depend on certain precise conditions of culture. The uptake of $\left[{ }^{3} \mathrm{H}\right]$ lysine was also measured in two of the six experiments; it was significantly increased by FSH in one of them. LH had no significant effect on lysine uptake. There were no significant interactions between FSH and LH. It is concluded that the uptake of labelled thymidine in response to FSH should have useful experimental applications. The possibility that the exclusive role of FSH is to initiate DNA synthesis in follicle cells is briefly discussed.
\end{abstract}

\section{INTRODUCTION}

In vitro culture procedures for ovary and testis provide an alternative to hypophysectomy for evading the pituitary feed-back and so facilitating investigation of the action of gonadotrophins. Such procedures permit more exact and continuous control of the hormone concentrations to which the target tissue is exposed than is possible in the intact animal. Moreover, tissue from very immature animals too small for hypophysectomy can be used and tissue from a single animal can be subjected to more than one treatment. Much experimental evidence on the metabolic effects of luteinizing hormone (LH) has been gained from 2-to-4-hr in vitro incubations of ovarian tissue (Savard, Marsh \& Rice, 1965; Savard, 1967), but only Hamberger \& Ahrén (1967) have detected positive effects after short-term incubations with highly purified folliclestimulating hormone (FSH). Responses have been detected in ovaries removed from animals injected with FSH $1 \frac{1}{2}$ to $6 \mathrm{hr}$ previously (Ahrén \& Rubinstein, 1965; Blackburn \& Kostyo, 1965; Given, Brown \& Hilliard, 1966). The development of readily detectable effects of FSH may require a time interval longer than the few hours normal for metabolic studies. A procedure for culturing intact ovaries from immature mice for several days was therefore developed.

Positive responses to pituitary explants or to purified gonadotrophins by 
ovaries cultured in vitro have been reported by Lostroh (1959), Pavić (1963), Fainstat (1966), Stokłosowa \& Koziorowska (1966) and Bousquet (1967). These workers noted qualitative morphological changes. For further studies on the properties and mode of action of FSH, a consistent, quantitative and preferably specific index of response was required. FSH stimulates follicle enlargement in vivo, due partly to mitosis of the follicle cells. The nucleoside, thymidine, is incorporated into DNA before mitosis. The quantity of radio-actively labelled thymidine incorporated into DNA is often used as a measure of mitotic activity. The present work describes the uptake of ${ }^{14} \mathrm{C}$-labelled thymidine, but not the measurement of its incorporation into DNA by immature mouse ovaries cultured in the presence of FSH. In order to check any additional direct or indirect action due to $\mathrm{LH}$ on $\left[{ }^{14} \mathrm{C}\right]$ thymidine uptake, both gonadotrophins were used in a series of experiments of factorial design. Moreover, since either hormone might affect cell enlargement and total protein synthesis per cell, the uptake of a tritium-labelled amino acid was measured simultaneously. The final and most extensive experiment is described in detail first, followed by a summary of the procedures and results for the whole series.

\section{Main experiment}

\section{MATERIALS AND METHODS}

Gonadotrophins. Highly purified human pituitary gonadotrophins were used. The FSH, prepared by the method of Butt, Crooke, Cunningham \& Wolf (1963), contained less than 0.012 i.u. LH/i.u. FsH as measured by the rat ovarian ascorbic acid depletion assay. The LH, prepared by the method of Hartree, Butt \& Kirkham (1964), contained less than 0.00009 i.u. FsH/i.u. LH by the mouse ovarian augmentation assay.

Tissue. Systematically random-bred mice of the small but prolific GFW strain were reared from birth in foster-litters of ten (Smith \& Ryle, 1968). One foster-litter provided the ovaries for each replicate set of experimental treatments. At 15 days, when used, the weight distribution of each litter was recorded, but individual mice were assigned at random to the different treatments. Each mouse was killed abruptly. The uteri with attached ovaries were removed aseptically and the ovaries were dissected out of their capsules as rapidly as possible. Similar ovaries weighed between 0.5 and $1 \mathrm{mg}$ per pair. Each pair of whole ovaries was put in a separate dish with no special care regarding their orientation. All ovaries flattened out during culture but they remained intact with no marked wandering of cells from the surface.

Culture procedure. The ovaries were put on a strip of lens tissue laid over a stainless steel mesh platform in a 5-cm diameter Petri dish. The platform was supported $4 \mathrm{~mm}$ above the floor of the dish, which contained $5 \mathrm{ml}$ of medium. The latter consisted of nineteen parts of a modified Eagle's medium (Vantsis \& Wildy, 1962) to one part of $5 \%(\mathrm{w} / \mathrm{v})$ crystalline bovine serum albumin (B.D.H.) in $0.9 \%$ saline (cf. Fritz, Gho \& Biggers, 1965). No serum was used, in order to avoid possible contamination by unknown quantities of gonadotrophins or steroids. Each dish, after preparation with its appropriate complement of hormones, was put in an individual jar in an atmosphere saturated with water-vapour. The jars were gassed with $5 \% \mathrm{CO}_{2}$ in air through tubes 
sealed into the metal lids and left overnight at $37^{\circ} \mathrm{C}$ for $\mathrm{pH}$ and temperature to stabilize before adding the tissue. After the ovaries had been put in, the jars were gassed with a mixture containing $5 \% \mathrm{CO}_{2}$ and approximately $30 \%$ oxygen.

Tracers. About $24 \mathrm{hr}$ after setting up the cultures, each dish received $0 \cdot 1 \mu \mathrm{C}$ of $\left[2-{ }^{14} \mathrm{C}\right]$ thymidine and $0.2 \mu \mathrm{C}$ of $\mathrm{L}-$ lysine-4,5T monohydrochloride $(60.5$ $\mathrm{mc} / \mathrm{mm}$ and $141 \mathrm{mc} / \mathrm{mm}$ respectively; Radiochemical Centre, Amersham), each in $0.2 \mathrm{ml}$ modified Eagle's medium. The jars were re-gassed and incubated for a further 3 days. The ovaries were then removed and prepared for counting.

Preparation and counting of tissue samples. Each grid was irrigated with about $5 \mathrm{ml}$ of $0.9 \%$ saline. The ovaries were then dissolved by heating in $0.1 \mathrm{ml}$ $1 \mathrm{~N}$-methanolic KOH. After evaporation $0.25 \mathrm{ml} 1 \mathrm{~m}$-methanolic hyamine-10-x chloride was added, followed by $6 \mathrm{ml}$ of the scintillator $(0.25 \%$ PPO plus $0.005 \%$ POPOP in toluene). The tritium and carbon- 14 in each sample were counted simultaneously in a Packard Liquid Scintillation Counter. The recorded counts were corrected for background, and, by automatic external standardization, for absorption by the fluid. In the case of tritium, a further correction was made for counts due to ${ }^{14} \mathrm{C}$ appearing in the tritium channel.

Design and analysis of experiment. A standard $3^{2}$ factorial design, with three replicates of each of the 9 treatments, was used. The concentrations of FSH were $0,0.5$ and 2.5 i.u. per dish $(5 \mathrm{ml})$. Those of LH were $0,1.0$ and 5.0 i.u. per dish. An analysis of variance was carried out on each of the three sets of data: ${ }^{14} \mathrm{G}$ count, tritium count and (tritium $\times 100$ ) $/{ }^{14} \mathrm{C}$. One ovary was lost when removing the tissue from one of the culture dishes. The counts recorded for the remaining ovary have been doubled to provide the figures used in the analyses.

\section{Series of experiments}

Table 3 summarizes some variations of the procedure and of the mice used in the series of experiments. Exp. $\mathrm{F}$ is that described in detail above. The following additional points of variation should be noted:

(1) In Exp. A, the mice were 16 or 17 days old instead of 15 days and the thirty-two ovaries for each set of sixteen $\left(4^{2}\right)$ treatments were dissected out, pooled and distributed at random to the dishes. This involved exposure to high $\mathrm{pH}$ and prolonged cooling.

(2) The jars were gassed with $5 \% \mathrm{CO}_{2}$ in air in Exps. A to E, extra oxygen being given in Exp. $\mathrm{F}$ only.

(3) In Exps. A to E, the ovaries were dissolved by putting them in $0.5 \mathrm{ml}$ 1 m-hydroxide of hyamine at $37^{\circ} \mathrm{G}$ overnight.

(4) No correction for scintillation absorption was available for Exps. A to $D$; calculations are based on crude counts. For the same reason no reliable lysine data are available for these experiments.

\section{Main experiment}

\section{RESULTS}

Tables 1 and 2 indicate the mean uptake of thymidine and lysine respectively with the various hormone combinations (treatments). The figure for 
each of the nine combinations is the mean of three replicates. The marginal means are derived from three such combinations, each with three replicates, containing a given level of either FSH or LH. The standard errors quoted below the tables refer to the marginal means. Analyses of variance showed that the increases in both thymidine and lysine uptake due to FSH were significant $(P<1 \%$ in each case) $; 0.5$ i.u./dish produced effects approaching the maximum possible under these conditions. Glearly LH had no effect on thymidine uptake,

TABLE 1

MEAN GOUNTS $/ 0 \cdot 1$ MIN OF $\left[{ }^{14} \mathrm{C}\right]$ THYMIDINE FOR EAGH TREATMENT AND EACH DOSE LEVEL OF FSH AND LH

\begin{tabular}{c|ccc|c}
\hline \multirow{2}{*}{ i.u. LH/dish } & \multicolumn{3}{|c|}{ i.u. FSH/dish } & \multirow{2}{*}{ Mean } \\
& 0 & $0 \cdot 5$ & $2 \cdot 5$ & \\
\hline 0 & 364 & 624 & 743 & 577 \\
$1 \cdot 0$ & 445 & 695 & 531 & 557 \\
$5 \cdot 0$ & 456 & 557 & 734 & 582 \\
\hline Mean & 422 & 626 & 669 & \\
\hline
\end{tabular}

S.E. of mean count for each FSH and LH dose level $= \pm 51$.

TABLE 2

MEAN COUNTS $/ 0 \cdot 1$ MIN OF $\left[{ }^{3} \mathrm{H}\right]$ LYSINE FOR EAGH TREATMENT AND EACH DOSE LEVEL OF FSH AND LH

\begin{tabular}{c|rrr|l}
\hline \multirow{2}{*}{ i.u. LH/dish } & \multicolumn{3}{|c|}{ i.u. FSH/dish } & \multirow{2}{*}{ Mean } \\
& 0 & 0.5 & $2 \cdot 5$ & \\
\hline 0 & 643 & 859 & 1135 & 879 \\
1.0 & 747 & 1252 & 923 & 974 \\
$5 \cdot 0$ & 757 & 998 & 1068 & 941 \\
\hline Mean & 716 & 1036 & 1042 & \\
\hline
\end{tabular}

S.E. of mean count for each FSH and LH dose level $= \pm 53$.

and the slight increase in lysine counts was not significant. Neither hormone significantly changed the lysine : thymidine ratio, so cell size apparently remained unaffected. There was no significant interaction between FSH and LH with respect to any of the three parameters.

Apart from FSH effects, there were significant differences between replicates with respect to both thymidine and lysine uptake $(P<1 \%$ and $<0.1 \%$, respectively). The two varied in parallel and probably relate to the mean size of the mouse, and more particularly of the ovaries, at the time of dissection. The largest replicate mean was 1.6 times the smallest for thymidine and 1.5 times that for lysine. 


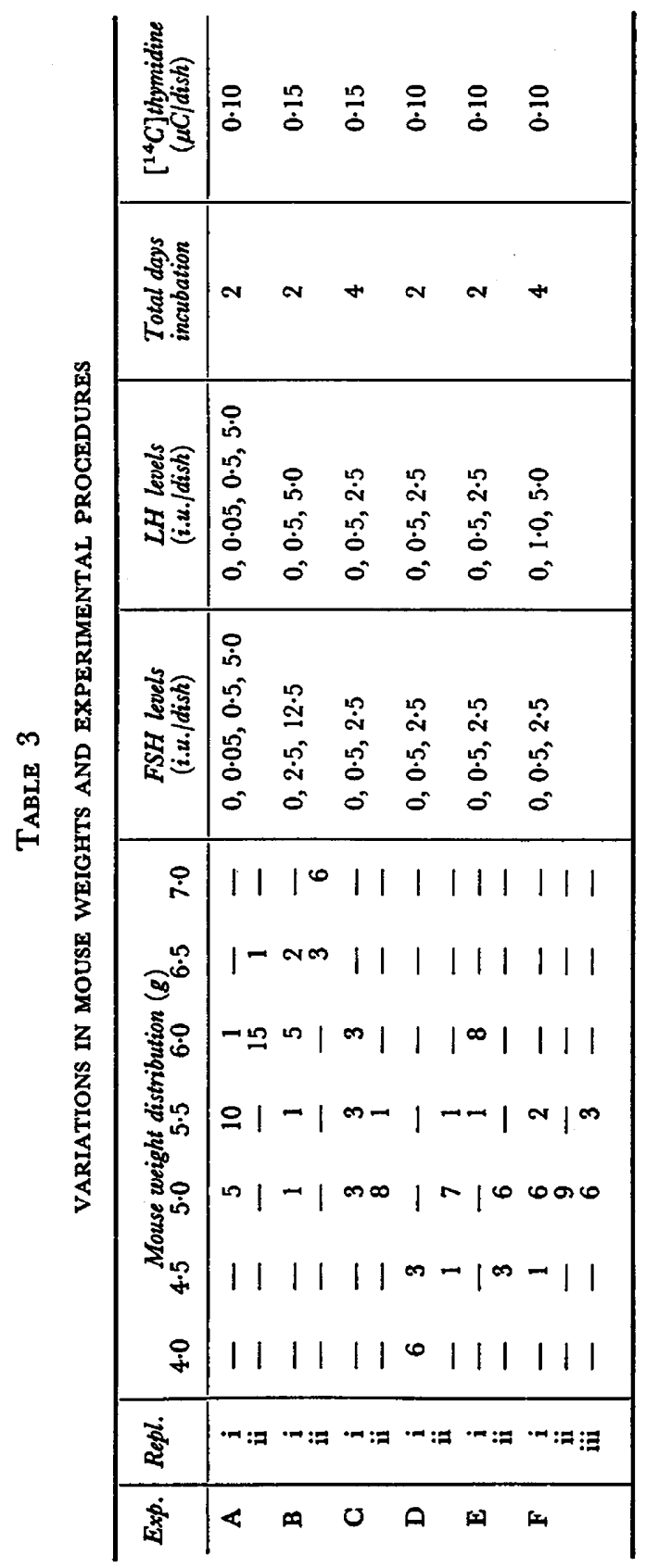




\section{Series of experiments}

In spite of the technical differences involved in the series of experiments, analyses of the results showed significant effects on thymidine uptake due to FsH in Exps. A, B and C $(P<5 \%,<1 \%,<1 \%$, respectively). Exps. D and E, which were identical, each included a replicate based on relatively small mice. If the data from the larger replicate of each are combined (Dii and Ei), the FSH effect is significant $(P<2.5 \%)$. In no experiment was thymidine uptake increased by as much as $100 \%$ at any dose level. This probably stems from limitations of the present culture procedure rather than from incapacity of the ovaries to respond further.

In Exps. A to E, in contrast to Exp. F, thymidine uptake was higher in the presence of $\mathrm{LH}$ than in its absence and in two $(\mathrm{C}$ and $\mathrm{Dii} / \mathrm{Ei})$ the increase was significant $(P<2.5 \%)$ in each case $)$. Exp. $F$ was the only one in which the jars were gassed with an oxygen-enriched mixture. This may be associated with the absence of an LH effect. There was no interaction between FSH and LH in any experiment.

There was no significant FsH effect on lysine uptake in Exp. $\mathbf{E}$ although the highest value was reached with 0.5 i.u. FSH, as in Exp. F. FSH reduced the mean lysine: thymidine ratio in Exp. E $(P<5 \%)$ suggesting that synthesis of new protein may have failed to keep pace with nuclear division. This again contrasts with Exp. F where the ratio did not vary significantly, perhaps because more oxygen was available and protein synthesis proceeded more rapidly. In Exp. E, as in Exp. F, LH had no significant effect on either lysine uptake or the lysine: thymidine ratio.

\section{DISCUSSION}

These results show that the ovaries of 15-day-old CFW mice, weighing $5 \mathrm{~g}$ or more, consistently respond in culture to FsH by increasing their uptake of labelled thymidine. Ben-Or (1963) observed a distinct change in sensitivity and in the type of morphological response to FSH at 12 to 15 days in intact mice. The $5 \mathrm{~g}$ threshold probably corresponds to this change. The ovaries respond in vitro at a dose range comparable to that used for in vivo assays and this quantitative response, which is relatively quickly measured, is suitable both as a test for FSH-type activity and for studying certain features of the ovarian reaction. At present, its use is restricted by the small percentage increase in FsH-treated compared to untreated ovaries, where mitoses certainly occur and thymidine is probably incorporated into DNA as well as being present in the free state. The results of Exp. F do not suggest that a labelled amino acid is likely to be preferable, for the maximum response was reached with $0.5 \mathrm{i}$.u./ dish, but improved culture techniques are likely to extend the range of response to FSH. Parallel morphological studies typically show pyknosis of central follicles. The use of serum in the medium should reduce pyknosis and increase the amount of responding tissue but if it contained much FSH, thymidine uptake would be maximal even in the control cultures. Since no interaction between FSH and LH occurs, low serum concentrations of LH might be tolerable but, in general, serum from hypophysectomized animals seems desirable. Exp. F 
suggests that with appropriate oxygen levels the effect of $\mathrm{LH}_{\mathrm{H}}$ in test materials as well as serum may be eliminated. If further work confirms this, and if other hormones prove to have no effect on thymidine uptake, the response could be made specific for FSH.

Preliminary morphological studies (Ryle, unpublished) indicate that FsH stimulates follicle cell division in similar ovary cultures, as it does in vivo, whereas LH does not. Therefore the present results due to Fsh probably correspond to increased incorporation of thymidine into new DNA and of lysine into new protein. If the main, perhaps even the exclusive, effect of FsH stimulation is the initiation of DNA replication in follicle cells, it should be possible to identify more immediate and more sensitive responses. The time scale here is in days but metabolic changes leading to DNA replication must occur within hours or minutes of stimulation. If FSH simply stimulates cell division, it may nevertheless affect steroid production by providing more cells on which LH can act. Since the amount of oestrogen produced by many cells responding to low concentrations of LH could equal that produced by few cells responding to high concentrations of $\mathbf{L H}$, oestrogen production alone may be a very rough guide to what is happening in the ovary.

\section{ACKNOWLEDGMENTS}

I am indebted to Dr A. C. Crooke for his constant encouragement, to Dr W. R. Butt for much advice on gonadotrophins and isotopes and for the supply of FSH, and to Mr P. V. Bertrand for help in the design and analysis of the experiments. Dr A. S. Hartree kindly provided the LH. The Eagle's medium was supplied by the Department of Virology, Birmingham University. Miss M. Wardill, Miss P. Smith, Miss M. Smith and Miss J. Gammons contributed enthusiastic technical assistance. The work was supported by a grant from the Ford Foundation.

\section{REFERENCES}

Ahré, K. \& RuBinstein, L. (1965) Effects of follicle-stimulating hormone on amino acid transport and protein biosynthesis in the isolated rat ovary. Acta physiol. scand. 64, 463.

BEN-OR, S. (1963) Morphological and functional development of the ovary of the mouse. I. Morphology and histochemistry of the developing ovary in normal conditions and after FSH treatment. 7. Embryol. exp. Morph. 11, 1.

BLAGKBURN, N. M. \& Kostyo, J. L. (1965) Stimulatory effect of follicle-stimulating hormone on amino acid incorporation into protein by a homogenate of rabbit ovaries. Biochim. biophys. Acta, 107, 168 .

BousQUET, J. (1967) Culture organotypique de fragments d'ovaires de ratte: actions de facteurs gonadotropes hypophysaire. C. r. Séanc. Soc. Biol. 161, 778.

Butt, W. R., Crooke, A. C., Cunningham, F. J. \& Wol.p, A. (1963) Biological and immunological properties of human pituitary follicle stimulating hormone obtained by starch gel electrophoresis. F. Endocr. 25, 541.

Crven, M., Brown, G. B. \& Hilliard, J. (1966) Ribonucleic acid and protein synthesis in ovary. Biochim. biophys. Acta, 114, 127.

FaINSTAT, T. (1966) Direct action of hormones on ovaries maintained in organ culture. Abstracts of 2nd Int. Congr. on Hormonal Steroids, Milan. Excerpta med. Int. Congr. Ser. 111, 258.

Fritz, H. I., Cho, W. K. \& BigGers, J. D. (1965) Ovulation from whole ovaries of mice in organ culture. F. Cell Biol. 27, 31A.

Hamberger, L. A. \& Ahrén, K. E. B. (1967) Effects of gonadotrophins in vitro on glucose uptake and lactic acid production of ovaries from prepubertal and hypophysectomized rats. Endocrinology, 81, 93. 
HARTree, A. S., BUtT, W. R. \& KIRKhaM, K. E. (1964) The separation and purification of human luteinizing and thyrotrophic hormones. F. Endocr. 29, 61.

LostroH, A. J. (1959) The response of ovarian explants from post-natal mice to gonadotropins, Endocrinology, $65,124$.

Pavic, D. (1963) The effect of gonadotrophic hormones on young rat ovaries grown in organ culture. $\mathcal{F}$. Endocr. 26, 531.

SAvard, K. (1967) Recent research on gonadotrophic hormones, p. 170. Eds. E. Trevor Bell and John A. Loraine. Livingstone, Edinburgh.

SAVARD, K., MARSh, J. M. \& RIGE, B. F. (1965) Gonadotrophins and ovarian steroidogenesis. Recent Prog. Horm. Res. 21, 285.

Smith, M. J. \& RyLe, M. (1968) An approach to the more economic production of uniform mice. $\mathcal{F}$. Inst. Anim. Tech. 19, 74.

Stoxzosowa, S. \& KoziorowskA, J. (1966) Effect of hormones on ovaries cultured in vitro. Zoologica Pol. 16, 139.

VANTsis, J. T. \& WILDY, P. (1962) Interaction of herpes virus and Hela cells: comparison of cell killing and infective center formation. Virology, 17, 225. 